\title{
EFFECT OF ETHANOL EXTRACT OF MANGOSTEEN PEEL ON SERUM MALONDIALDEHYDE AND LEUKOTRIENE B4 LEVELS IN MALE WHITE RATS (Rattus norvegicus) WISTAR STRAIN EXPOSED WITH ELECTRIC CIGARETTE SMOKE
}

\author{
Jemima Lewi Santoso ${ }^{1}$, Harianto Notopuro ${ }^{2}$, Ema Qurnianingsih ${ }^{2}$ \\ ${ }^{1}$ Master Program of Basic Medical Science, ${ }^{2}$ Department of Biochemistry, Faculty of Medicine, Universitas \\ Airlangga, Surabaya, Indonesia
}

\section{ABSTRACT}

\begin{abstract}
This study aimed to analyze the administration of mangosteen peel ethanol extract at different doses can reduce levels of malondialdehyde (MDA) and leukotriene B4 (LTB4) serum in male white rats (Rattus norvegicus) Wistar strains exposed to electric cigarette smoke. Electric cigarette induces mitochondrial ROS production and triggers oxidative stress. Antioxidants are needed by the body if there are many free radicals, for example mangosteen peel. This laboratory experimental study uses a randomized post-test only control group design. Thirty male white rats were divided into 5 groups randomly $(K K, K R, P 1, P 2$, P3). KK given 0.5\% Na-CMC, KR given smoke and $0.5 \% \mathrm{Na}-\mathrm{CMC}, \mathrm{P1}, \mathrm{P} 2, \mathrm{P3}$ given smoke and mangosteen peel ethanol extract 100, 200, $300 \mathrm{mg} / \mathrm{kg}$ weight. Data were tested for normality and homogeneity tests. Data distribution was found not normal. Data were tested by Kruskal-Wallis Test and Mann-Whitney. Kruskal-Wallis Test results showed significant differences in MDA and LTB4 levels in each experimental group (KS, KR, P1, P2 and P3), $p<0.05$. Mann-Whitney test results showed a significant difference in the MDA levels of the KR against P3 and in the LTB4 level of the KR against P2 $(p<0.05)$. The conclusion of the study was the administration of mangosteen peel ethanol extract can reduce MDA and LTB4 levels serum in male white rats (Rattus norvegicus) Wistar strains exposed to electric cigarette smoke.
\end{abstract}

Keywords: Mangosteen; MDA; LTB4; electric cigarette

\section{ABSTRAK}

Penelitian ini bertujuan untuk menganalisis pemberian ekstrak etanol kulit manggis pada dosis yang berbeda dapat mengurangi kadar malondialdehyde (MDA) dan serum leukotriene B4 (LTB4) pada tikus putih jantan (Rattus norvegicus) strain Wistar yang terpapar asap rokok listrik. Rokok listrik menginduksi produksi ROS mitokondria dan memicu stres oksidatif. Antioksidan dibutuhkan oleh tubuh jika ada banyak radikal bebas, misalnya kulit manggis. Penelitian eksperimental laboratorium ini menggunakan desain kelompok kontrol uji acak saja. Tiga puluh tikus putih jantan dibagi menjadi 5 kelompok secara acak (KK, KR, P1, P2, P3). KK diberikan 0,5\% Na-CMC, KR diberikan asap dan 0,5\% Na-CMC, P1, P2, P3 diberikan asap dan ekstrak etanol kulit manggis 100, 200, $300 \mathrm{mg} / \mathrm{kg}$ berat. Data diuji untuk uji normalitas dan homogenitas. Distribusi data ditemukan tidak normal. Data diuji dengan Uji Kruskal-Wallis dan Mann-Whitney. Hasil Uji Kruskal-Wallis menunjukkan perbedaan yang signifikan dalam kadar MDA dan LTB4 pada setiap kelompok eksperimen (KS, KR, P1, P2 dan P3), $p<0,05$. Hasil uji Mann-Whitney menunjukkan perbedaan yang signifikan dalam kadar MDA KR terhadap P3 dan pada LTB4 kadar KR terhadap P2 $(p<0,05)$. Kesimpulan dari penelitian ini adalah pemberian ekstrak etanol kulit manggis dapat menurunkan kadar MDA dan LTB4 serum pada tikus putih jantan (Rattus norvegicus) galur Wistar yang terpapar asap rokok listrik.

Kata kunci: Buah manggis; MDA; LTB4; rokok elektrik

Correspondence: Jemima Lewi Santoso, Jalan Darmo Permai Utara XI no 59, Surabaya, Indonesia. Phone: 085769188866. E-mail: jemima.lewi@ciputra.ac.id

pISSN:2355-8393 • eISSN: 2599-056x • doi: http://dx.doi.org/10.20473/fmi.v56i4.23413

- Fol Med Indones. 2020;56:283-289 • Received 9 Sept 2019• Accepted 12 Mar 2020

- Open access under CC-BY-NC-SA license • Available at https://e-journal.unair.ac.id/FMI/

\section{INTRODUCTION}

Mangosteen peel is rich in antioxidant bioactive compounds, namely, polyphenolic compounds, including xanthones, anthocyanins (Kanti \& Syed 2009), proanthocyanidins (Raharjo \& Santoso, 2013)
(Santoso 2015) and catechin (Hiranrangsee et al 2016). About 50 types of xanthone compounds were successfully isolated from mangosteen peel (Darmawansyih 2014). Xanthones on mangosteen peel are also antidiabetic, anti-inflammatory (Wiwin 2010), anticancer (Akao et al 2008), anti-bacterial and 
antifungal (Hermawan 2016). Xanthones are soluble in alcohol and oil and are not soluble in water (Sumarny et al 2015).

Anthocyanins are good antioxidants to prevent or reduce the risk of disease. The content of anthocyanins in mangosteen peel is very high (Chaovanalikit and Mingmuang, 2007) (Hiranrangsee et al., 2016). Anthocyanins in the mangosteen peel consist of cyaniding-sophoroside, cyanidingglucoside-pentoside, cyaniding-glucoside, and cyaniding glucoside- $\mathrm{X}$ (X indicates a compound that is not identified and is incompatible with general sugar residues). Cyanidin-3sophoroside and cyanidin-3-glucoside are the main anthocyanin compounds in mangosteen peel and are the only ones that increase with the development of a darker skin color (Palapola et al 2009). The content of anthocyanin extracted by maceration of mangosteen pericarp dried was $21.19 \pm 0.49 \mathrm{mg}$ Cyn-3-Glu/100 g (Hiranrangsee et al 2016) and $1403 \pm 122.9 \mathrm{mg} \mathrm{Cy}-3$ Sop/100 g (Palapola et al 2009). Cyanidin-3-glucoside has been shown to have a large oxygen radical absorbance capacity (ORAC) in vitro (Lee et al 2017).

This anthocyanin compound also shows biological activity as antidiabetic, antibacterial, anti-inflammatory, anti-cancer and anti-tumor (Hiranrangsee et al 2016). Anthocyanins are soluble in water and most organic solvents (Khoo et al., 2017).

The way anthocyanin works as an antioxidant through direct and indirect pathways. The direct pathway is anthocyanin directly scavenging free radicals and thus reduces oxidative stress. The indirect pathway involves the downregulation of cell proliferation and apoptosis, namely the downregulation of the activity of the enzyme cyclooxygenase (COX-1 and COX-2). These enzymes catalyze the formation of leukotrienes, prostacyclin, prostaglandins (PG), and thromboxan (Khoo et al 2017).

Electric cigarettes are marketed as an alternative product if one day conventional cigarettes are not permitted (Kennedy et al., 2017). The use of e-cigarettes has increased in recent years; an increase in the prevalence of adults using e-cigarettes in Indonesia in 2011 by $0.3 \%$, Italy in 2013 by $1.2 \%$, Greece in 2013 by $1.9 \%$ and Poland in 2010-2011 by 5.9\% (Breland et al ., 2017). Farsalinos research in 2015 found that the dose of particles caused by electric cigarettes is the same as the dose of particles caused by conventional cigarettes. Electric cigarette smoke shows oxidant and reactivity of reactive oxygen species that are similar to conventional cigarette smoke (Pisinger 2014).

Learner et al. in 2015 found that electronic cigarette aerosols and copper nanoparticles induced the production of mitochondrial ROS, mitochondrial stress (reducing the stability of electron transport OxPhos chain (ETC) complex IV subunits) and DNA fragmentation in lung fibroblasts. Acrolein has been shown to trigger oxidative stress and inflammation, which results in loss of integrity of the endothelial cell barrier in the lungs. Propylene glycol, glycerin, and methanol have been shown to increase hydrogen peroxide production. Flavoring additives from cinnamon rolls stimulate increased production of IL-8 inflammatory cytokines in pulmonary fibroblasts (Cai and Wang, 2017).

Examination of electron paramagnetic/spin resonance or electron paramagnetic/spin resonance (EPR/ESR) shows the production of free radicals from the results of the evaporation of electric cigarettes, namely increased lipid peroxidation in pulmonary homogenates (assessed from thiobarbituric reactive acid or thiobarbituric acid reactive substances (TBARS)) mice exposed to electric cigarettes. A $58 \%$ increase in the number of macrophages in bronchoalveolar lavage (LAB) 24 hours after final exposure (twice per day for two weeks) accompanied by an increase in IL-6 production. This results in reduced defense against bacteria and viruses. In healthy human subjects, the use of e-cigarettes triggers oxidative stress, decreased nitric oxide, and endothelial/vascular dysfunction resulting in impaired blood flow (dilatation). Moheimani et al in 2015 reported the occurrence of oxidative stress and increased sympathetic activity of the heart in e-cigarette users. This is a risk factor for cardiovascular disease. Oxidative stress due to exposure to e-cigarettes can trigger cardiopulmonary pathogenesis, neurodegenerative disorders and cancer (Cai \& Wang 2017).

Oxidants due to exposure to electric cigarettes can trigger the pathogenesis of lung disease, for example, chronic obstructive pulmonary disease (COPD) (Cai and Wang, 2017). Chronic obstructive pulmonary disease (COPD) is one of the leading causes of chronic morbidity and mortality worldwide. Chronic obstructive pulmonary disease is currently the fourth largest cause of death in the world but is predicted to be the 3rd leading cause of death in 2020 (Gerald and Bailey, 2018). World health organization (WHO) said COPD is the fourth leading cause of death in the world (Oemiati 2013). Based on data from Basic Health Research (Rikesdas) in 2013, the prevalence of COPD disease in Indonesia reached $3.7 \%$ (Indonesian Ministry of Health's Health Research and Development Agency, 2013). The main risk factors for COPD are tobacco smoking (Gerald \& Bailey 2018) although other factors such as occupational factors are often exposed to hazardous materials/gases (coal, silica, cotton, heavy 
metals) and air pollution (carbon and sulfur dioxide formed when burning fossil fuels of coal or diesel oil) also affects the occurrence of COPD (Hermawan 2016).

Lipid peroxidation is a major consequence of oxidative stress and a cause of oxidative damage. Malondialdehyde (MDA) is a lipid peroxidation product that has been recognized as an oxidative stress biomarker (Safyudin \& Subandrate 2016). Increased MDA concentration is used as a biomarker of oxidative stress in various health problems such as cancer, psychiatric disorders, chronic obstructive pulmonary disease, asthma, or cardiovascular disease (Khoubnasabjafari et al 2015).

Interleukin-8 and Leukotrien B4 (LTB4) are known as neutrophil chemotactic factors which will activate and recruit neutrophils into the airway. Leukotriene B4 is preferred in experimental research to reflect the process that occurs in humans because only LTB4 is owned by humans and rat (Rattus norvegicus) Wistar strains. Leukotrienes B4 contribute to many inflammatory diseases, including COPD (O'Dwyer et al., 2015). High levels of LTB4 in plasma show a strong proinflammatory response and serve to identify the risk of developing lung complications (Auner et al 2012).

This study aims to analyze the administration of mangosteen peel ethanol extract at different doses can reduce levels of malondialdehyde (MDA) and leukotriene B4 (LTB4) serum in male white rats (Rattus norvegicus) Wistar strains exposed to electric cigarette smoke for 4 weeks.

\section{MATERIALS AND METHODS}

Experimental research using a randomized post-test only control group design. The independent variables of the study were mangosteen peel extract and electric cigarette smoke. The dependent variables of the study were MDA and Leukotriene B4 serum.

The study used samples of experimental animals total 30 male white rats (Rattus norvegicus) Wistar strains with criteria for age 2-3 months, body weight 170-180 g healthy physical. Acclimatization of laboratory conditions is carried out for 7 days. The weight of all mice was weighed after acclimatization. Experimental animals were divided into 5 groups randomly (1 group containing 6 mice), Group 1 was the negative control group/without exposure to electric cigarette smoke and was given a placebo (KK), Group 2 was the group given exposure to electric cigarette smoke and given a placebo (KR), Group 3 is a treatment group that is given exposure to electric cigarette smoke and mangosteen peel ethanol extract at a dose of $100 \mathrm{mg} / \mathrm{kg} \mathrm{BW} /$ day (P1), Group 4 is a treatment group that is given exposure to electric cigarette smoke and ethanol extract of mangosteen peel with dose of $200 \mathrm{mg} / \mathrm{kg}$ body weight/day (P2), Group 5 is the treatment group given exposure to electric cigarette smoke and ethanol extract of mangosteen peels with a dose of $300 \mathrm{mg} / \mathrm{kg}$ body weight/day (P3).

Exposure to e-cigarette smoke is given from day 1 to day 28. The liquid cigarette smoke is evaporated/heated to form smoke. Each group of rats (except the KK group) was put into a hollow glass box. The box is connected to the connection of the rubber eagle and the iron pipe which has 2 ends. The first end is connected to the hole of the glass box and the second end is connected to the solder which functions to vaporize the e-cigarette liquid. The entire body of the animal is exposed to electric cigarette smoke. Negative control group rats were exposed to free air. One group of rats was exposed to e-cigarette smoke once a day with a dose of e-cigarette liquid 8 drops/ $\mathrm{x}$ every day for 4 weeks (Glynos et al., 2018). The composition of ecigarettes used in this research is propylene glycol $30 \%$, vegetable glycerin $70 \%$, flavorings/flavor $40 \%$, sweetener.

Provision of placebo and ethanol extract of mangosteen peel is given on days 15-28. Provision is done 1 hour before being exposed to electric cigarette smoke. Group $\mathrm{KK}$ and $\mathrm{KR}$ was given a $5 \% \mathrm{Na}-\mathrm{CMC} \mathrm{O}$ solution (placebo). Group P1, P2 and P3 were given ethanol extract of mangosteen peel at a dose of $100,200,300 \mathrm{mg} / \mathrm{kgBB} /$ day in $5 \% \mathrm{Na}-\mathrm{CMC} \mathrm{O}$ solution. Placebo and ethanol extract of mangosteen rind in NaCMC O solution, $5 \%$ given orally through gastric sonde. On the 29th day, rats in all groups were terminated. Blood is drawn through intra-cardiac puncture using a 5 $\mathrm{ml}$ syringe and a $23 \mathrm{G}$ needle. Blood is stored in a vacuum tube with a gold cap (without EDTA) for centrifuge to obtain serum and parameter checks. Serum MDA levels were examined using thiobarbituric acid (TBA) reagents. Serum Leukotriene B4 levels were measured by a competitive Elisa method using the Rat Leukotriene B4 ELISA Kit from Elabscience, Inc. with catalog number E-EL-006.

Data of serum MDA and LTB4 levels were calculated on average (mean) and standard deviation (SD) and were performed normality tests with one sample Kalmogorov-Smirnov and homogeneity tests with Levene. Normal distribution uses the Anova one-way test and the LSD (Least Significance Difference) test. Abnormal data distribution was tested using the Kruskal-Wallis Test and the Mann-Whitney Test. 


\section{RESULTS}

Serum MDA levels in each group can be seen in Table 1 , while rerum LTB4 levels in each group can be seen in Table 2. The data were processed in SPSS software (Statistical Package for the Social Sciences) version 20.0 and calculated the mean (mean) and standard deviation (SD) and conducted a normality test with Shapiro Wilk. The results of mean and standard deviation (SD) analysis of serum MDA and LTB4 levels can be seen in Table 3 .

Table 4 shows the $\mathrm{p}$ value $<0.05$ for each parameter measured and concluded that the data were not normally distributed at each of the examined levels. Data analysis using non-parametric test, the Kruskal-Wallis Test. The results of the Kruskal-Wallis Test can be seen in table 5.

Table 1. Serum MDA levels in each group of experimental animals

\begin{tabular}{clllll}
\hline \multirow{2}{*}{ Sample } & \multicolumn{5}{c}{ MDA (nmol/ml) } \\
\cline { 2 - 6 } & \multicolumn{1}{c}{ KK } & \multicolumn{1}{c}{ KR } & \multicolumn{1}{c}{ P1 } & \multicolumn{1}{c}{ P2 } & \multicolumn{1}{c}{ P3 } \\
\hline 1 & 12.072 & 41.539 & 8.976 & 8.976 & 8.288 \\
2 & 13.218 & 13.218 & 13.448 & 14.594 & 9.090 \\
3 & 11.613 & 33.513 & 15.282 & 6.797 & 8.861 \\
4 & 9.090 & 37.182 & 19.410 & 13.562 & 9.778 \\
5 & 14.480 & 20.556 & 12.416 & 12.760 & 10.696 \\
6 & 11.384 & 31.679 & 3.357 & 7.027 & 8.747 \\
\hline
\end{tabular}

Table 2. Serum LTB4 levels in each group of experimental animals

\begin{tabular}{crrrrc}
\hline \multirow{2}{*}{ Sample } & \multicolumn{5}{c}{ LTB4 $(\mathrm{pg} / \mathrm{ml})$} \\
\cline { 2 - 6 } & KK & KR & P1 & P2 & P3 \\
\hline 1 & 113.80 & 293.80 & 239.30 & 87.20 & 186.40 \\
2 & 158.40 & 443.30 & 122.90 & 164.70 & 112.00 \\
3 & 117.10 & 380.50 & 141.90 & 238.60 & 236.00 \\
4 & 128.30 & 438.30 & 293.30 & 220.90 & 283.30 \\
5 & 263.80 & 190.00 & 109.10 & 99.00 & 390.00 \\
6 & 218.70 & 664.60 & 340.00 & 325.50 & 315.00 \\
\hline
\end{tabular}

Table 3. Mean and standard deviations of serum MDA and LTB4

\begin{tabular}{lc}
\hline Level & Mean \pm standard deviations \\
\hline MDA & $14.72 \pm 9.28$ \\
LTB4 & $243.86 \pm 130.78$ \\
\hline
\end{tabular}

Table 4. Test for normality of serum MDA and LTB4 levels

\begin{tabular}{cccc}
\hline \multirow{2}{*}{ Level } & \multicolumn{3}{c}{ Shapiro Wilk } \\
\cline { 2 - 4 } & Statistic & Df & $\mathrm{p}$ \\
\hline MDA & 0.766 & 30 & 0.000 \\
LTB4 & 0.900 & 30 & 0.008 \\
\hline
\end{tabular}

Table 5. Kruskal-Wallis Test for serum MDA and LTB4

\begin{tabular}{llll}
\hline \multirow{2}{*}{ Level } & \multicolumn{3}{l}{ Kruskal-Wallis } \\
\cline { 2 - 4 } & Statistic & Df & $\mathrm{p}$ \\
\hline MDA & 14.509 & 4 & $0.006^{*}$ \\
LTB4 & 10.099 & 4 & $0.039 *$ \\
\hline *p $<0.05 \rightarrow$ significant differences &
\end{tabular}


Table 6. Mann-Whitney Test for MDA and LTB4 levels

\begin{tabular}{llll}
\hline & & MDA & LTB4 \\
\cline { 3 - 4 } & & $\mathrm{p}$ & $\mathrm{p}$ \\
\hline $\mathrm{KK}$ & $\mathrm{KR}$ & $0.004^{*}$ & $0.009^{*}$ \\
& $\mathrm{P} 1$ & 0.7 & 0.6 \\
& $\mathrm{P} 2$ & 0.7 & 0.82 \\
$\mathrm{KR}$ & $\mathrm{P} 3$ & $0.009^{*}$ & 0.18 \\
& $\mathrm{P} 1$ & $0.015^{*}$ & $0.03^{*}$ \\
& $\mathrm{P} 2$ & $0.009^{*}$ & $0.03^{*}$ \\
$\mathrm{P} 1$ & $\mathrm{P} 3$ & $0.002^{*}$ & 0.09 \\
& $\mathrm{P} 2$ & 0.59 & 0.59 \\
$\mathrm{P} 2$ & $\mathrm{P} 3$ & 0.18 & 0.59 \\
$* \mathrm{p}<0.05 \rightarrow$ significant differences &
\end{tabular}

Table 6 shows the significant differences in the MDA levels of the KK group against the MDA levels of the $\mathrm{KR}$ and $\mathrm{P} 3$ groups and the significant differences in the MDA levels of the KR group against the P1, P2 and P3 groups. Table 6 also shows a significant difference in the LTB4 levels of the KK group against the LTB4 levels of the KR group and a significant difference in the LTB4 levels of the KR group against groups P1 and P2.

\section{DISCUSSION}

Electrical smoking can cause COPD disease because exposure to e-cigarette smoke increases oxidative stress, triggers inflammation, interferes with autophagy and reduces resistance to bacteria and viruses (Cai and Wang, 2017).

\section{Malondialdehyde (MDA)}

Malondialdehyde (MDA) is used as an indicator of lipid peroxidation resulting from oxidative stress (Herlina et al 2017). Malondialdehyde is formed by autoxidation and enzyme degradation of polyunsaturated fatty acids in cells. The secondary end product of oxidation of these polyunsaturated fatty acids reacts with two molecules of thiobarbituric acid (TBA) through acidcatalyzed nucleophilic-addition reaction to produce pink-pink chromagen with maximum absorbance at 532 nm (Hodges et al 1999).

Reactive oxygen species (ROS) are typical free radicals that are produced during oxidative stress. The best known ROS signaling is through the respiratory chain. This involves the electron transfer reaction pathway, where the enzyme superoxide dismutase (SOD) produces hydrogen peroxide $(\mathrm{H} 2 \mathrm{O} 2)$ in the mitochondria. In complexes I and III in the mitochondria produce hydroxyl radicals (, Ä $\notin \mathrm{OH})$ produced by the Fenton reaction $((\mathrm{H} 2 \mathrm{O} 2+\mathrm{Fe} 2+$, ̈̈í , $\mathrm{A} \not \mathrm{OH}+\mathrm{OH}$,ài $+\mathrm{Fe} 3+)$. Anthocyanin is a reducing agent in the electron transfer reaction pathway (direct path). This direct pathway consists of 2 pathways, the first pathway is the "attack" of the hydroxyl group of the B-ring of the theanthocyanin structure and the second is the "attack" of the ionic ion on the C-ring (Khoo et al., 2017). The indirect pathway is via the nuclear factor-B signaling pathway, NF-" ${ }^{\circ} \mathrm{B}$ which is the main link between a large number of metabolic signals and inflammation. Nuclear factor-" ${ }^{\circ} \mathrm{B}$ is a transcription factor that is sensitive to oxidative stress and inflammation itself. Nuclear factor-B is expressed everywhere by cells and is located in the cytoplasm, where it is in an inactive form (Vendrame \& Klimiszacas 2015).

Stressors (including oxidative stress) activate nuclear factors $(\mathrm{NF})-{ }^{\circ \mathrm{B}}$, which results in an increase in the expression of proinflammatory cytokines for example interleukin (IL) -6 and tumor necrosis factor (TNF)- $\alpha$. This modulates the expression of systemic inflammatory mediators (e.g., C-reactive protein (CRP) and inhibits anti-inflammatory mediators such as adiponectin. Nuclear factor-B activation also increases the expression of inducible nitric oxide synthase (iNOS) and cyclooxygenase 2 (COX-2). In conditions where proinflammation, excess nitric oxide (NO) is converted to highly reactive peroxynitrite (while COX-2 leads to the formation of proinflammatory prostases and vasoconstriction such as PGE2 and PGF2 $\alpha$. Reduction of oxidative stress by anthocyanins results in the activation of NF-B being inhibited so that it inhibits the entire cascade of proinflammation and vasoconstriction such as PGE2 and PGF2 $\alpha$ (Vendrame \& Klimis-zacas 2015). This mechanism results in a weak inflammatory response. This was proven in an in vivo study that showed that lipopolysaccharide-induced mice fed $10 \%$ blueberries (containing anthocyanin) had reduced TNF- 
$\alpha$ and IL-6 protein and mRNA expression in serum compared with controls (Khoo et al 2017).

Table 6 shows a significant difference in the MDA levels of the KS group against the MDA levels of the $\mathrm{KR}$ and $\mathrm{P} 3$ groups and a significant difference in the MDA levels of the KR group against groups P1, P2 and P3. This shows that serum MDA levels from the KR group were significantly higher than the control group (KS) and the treatment group (P1, P2 and P3). The most significant difference (the smallest $\mathrm{p}$ value) was found in the MDA levels of the KR group against the MDA levels of the P3 group $(p=0.002)$. This shows that serum MDA levels decreased most significantly at a dose of $300 \mathrm{mg} / \mathrm{kg} \mathrm{BW} /$ day. Anthocyanin in the ethanol extract of mangosteen rind can reduce serum MDA levels in rats exposed to electric cigarette smoke.

\section{Leukotriene B4 (LTB4)}

Leukotriene B4 (LTB4) is a pro-inflammatory mediator that is synthesized in myeloid cells and is derived from arachidonic acid. Leukotriene B4 (LTB4) synthesis is enhanced by inflammatory mediators including endotoxin, complement fragments, tumor necrosis factor and interleukin. Increased intracellular free calcium in response to various inflammatory stimulations activates phospholipase A2 in the nuclear envelope cleaving arachidonic acid (AA) of phospholipids (Crooks \& Stockley 1998). Arachidonic acid (AA) which has been released by phospholipase A2 undergoes oxygenation at C-5 position by 5lipoxygenase (5-LOX) to form $5(\mathrm{~S})$-hydroperoxy-6E, 8Z, 11Z, 14Z eicosatetraenoic acid [5 (S) -HpETE], and subsequently to form leukotriene A4 (LTA4). 5(S)hydroperoxy-6E, 8Z, 11Z, 14Z eicosatetraenoic acid [5(S)-HpETE] is further hydrolyzed by LTA4 hydrolase to produce LTB4 (Saeki \& Yokomizo 2017).

The availability of AA depends on the level of activation of membrane phospholipase and the rate of reincorporation of AA to membrane phospholipid. Increased AA release is stimulated by various signaling molecules including endotoxin, C5a, TNF $\alpha$, IL-1, GMCSF, PAF (platelet activating factor), neutrophil elastase and LTB4 itself. All of these stimuli increase LTB4 production but all these stimuli can be inhibited by anthocyanin antioxidant properties both through direct and indirect channels (in the malondialdehyde section) (Saeki \& Yokomizo 2017).

Table 6 shows a significant difference in the LTB4 levels of the KS group against the LTB4 levels of the KR group and a significant difference in the LTB4 levels of the KR group against groups P1 and P2. The most significant difference (the smallest $p$ value) was found in the LTB4 level of the KS group against the LTB4 level in the KR group $(p=0.009)$. This shows that serum LTB4 levels from the KR group were significantly higher than the control group (KS) and the treatment group (P1 and P2) and the serum LTB4 levels decreased significantly when the dose of the mangosteen rind ethanol extract was increased at a dose of $200 \mathrm{mg} / \mathrm{kg} \mathrm{BW} /$ day. At a dose of $300 \mathrm{mg} / \mathrm{kgBW} /$ day there was no significant difference compared to a dose of $200 \mathrm{mg} / \mathrm{kgBW} /$ day, i.e., LTB4 levels in the P2 group against LTB4 levels in the P3 group (p) $>0.05$. Anthocyanin in the ethanol extract of mangosteen rind can reduce serum LTB4 levels in rats exposed to ecigarette smoke at a dose of $200 \mathrm{mg} / \mathrm{kgBW} /$ day.

\section{CONCLUSION}

The conclusion based on the results of the current study is that the administration of mangosteen peel ethanol extract at a dose of $100 \mathrm{mg} / \mathrm{kg} \mathrm{BW} /$ day, $200 \mathrm{mg} / \mathrm{kg}$ $\mathrm{BW} /$ day and $300 \mathrm{mg} / \mathrm{kg} \mathrm{BW} /$ day can reduce serum MDA and LTB4 levels in rats exposed to electric cigarette smoke for 4 weeks.

\section{ACKNOWLEDGMENT}

This study is supported by guidance from the Department of Biochemistry of Airlangga University and funding from Ciputra University. I would like to say special thanks to Professor Dr. Harianto Notopuro and Dr. Ema Qurniingsih for research advice and discussion on the selection of bioactive compounds.

\section{REFERENCES}

Akao Y, Nakagawa Y, Linuma M, Nozawa Y (2008). Anti-cancer effects of xanthones from pericarps of mangosteen. International Journal of Molecular Sciences 9, 355-370

Auner B, Geiger EV, Henrich D, Lehnert M, Marzi I, Relja B (2012). Circulating leukotriene b4 identifies respiratory complications after trauma. Mediators of Inflammation 2012

Breland A, Soule E, Lopez A, Ram $¥$ ¥a C, El-Hellani A, Eissenberg T (2016). Electronic cigarettes: what are they and what do they do?. Annals of The New York Academy of Sciences 1394, 1-26

Cai HL and Wang C (2017). The redox dark side of ecigarettes;exposure to oxidants and public health concerns. Redox Biology, 402-406

Chaovanalikit A and Mingmuang A (2007). Anthocyanin and total phenolic content of mangosteen and its juices. SWU Sci. J. 23, 68-78 
Crooks SW and Stockley R (1998). Molecules in focus Leukotriene B4. The International Journal of Biochemistry \& Cell Biology 30, 173-178

Darmawansyih (2014). Khasiat buah manggis untuk kehidupan. Jurnal Al Hikmah 15, 60-68

Gerald LB and Bailey WC (2018). Global Initiative for chronic obstructive lung disease. Journal of Cardiopulmonary Rehabilitation 22, 4, 234-244

Glynos C, Bibli SI, Katsaounou P, Pavlidou A, Magkou C, Karavana V, Topouzis S, Kalomenidis I, Zakynthinos S, Papapetropoulos A (2018). Comparison of the effects of e-cigarette 1 vapor with cigarette smoke on lung function and inflammation in mice. Am. J. Physiol. Lung Cell Mol. Physiol. $315,5,662-672$

Health Research and Development Agency Ministry of Health Republic of Indonesia (2013). Riset kesehatan dasar 2013. Bakti Husada, 1-303

Herlina, Aziz SA, Kurniawati A, Faridah DN (2017). Changes of thymoquinone, thymol, and malondialdehyde content of black cumin (Nigella sativa L.) in response to Indonesia tropical altitude variation. Hayati Journal of Biosciences 24, 156-161

Hermawan IP (2016). Pengaruh pemberian ekstrak kulit manggis (Garcinia mangostana Linn) terhadap nekrosis glomerulus dan tubulus ginjal mencit jantan (Mus musculus) yang di papar asap rokok skripsi.

Hiranrangsee L, Kumaree KK, Sadiq MB, Anal AK (2016). Extraction of anthocyanins from pericarp and lipids from seeds of mangosteen (Garcinia mangostana L.) by ultrasound-assisted extraction (UAE) and evauation of pericarp extract enriched functional ice cream. J. Food Sci. Technol. 53, 10, 3806-3813

Hodges DM, DeLong JM, Forney CF, Prange RK (1999). Improving the thiobarbituric acid-reactivesubstances assay for estimating lipid peroxidation in plant tissues containing anthocyanin and other interfering compounds. Planta 207, 604-611

Kanti BP and Syed IR (2009). Plant polyphenols as dietary antioxidants in healyth and disease. Oxidative Medicine and Cellular Longevity 2, 270278

Kennedy RD, Awopegba A, DeLe $\sqrt{ } \geq \mathrm{n}$ E, Cohen JE (2017). Global approaches to regulating electronic cigarettes. Tobacco Control 26, 440-445

Khoo HE, Azlan A, Tang ST, Lim SM (2017). Anthocyanidins and anthocyanins: colored pigments as food, pharmaceutical ingredients, and the potential health benefits. Food \& Nutrition Research 61,1

Khoubnasabjafari M, Ansarin K, Jouyban A (2015). Reliability of malondialdehyde as a biomarker of oxidative stress in psychological disorders. BioImpacts 5, 123-127
Lee C, Ying T, Chiou H, Hsieh S, Wen S, Chou R, Hsieh Y (2017). Alpha-mangostin induces apoptosis through activation of reactive oxygen species and ASK1/p38 signaling pathway in cervical cancer cells. Oncotarget 8, 47425-47439

O'Dwyer CA, O'Brien ME, Wormald MR, White MM, Banville N, Hurley K, McCarthy C, McElvaney NG, Reeves EP (2015). The BLT1 inhibitory function of E \pm-1 Antitrypsin augmentation therapy disrupts Leukotriene B 4 neutrophil signaling. The Journal of Immunology 195, 3628-3641

Oemiati R (2013). Kajian epidemiologis penyakit paru obstruktif kronik (PPOK). Media Litbangkes 23, 2, 82-88

Palapola Y, Ketsaa S, Stevensonb D, Cooneyb JM, Allanc AC, Fergusonc IB (2009). Colour development and quality of mangosteen (Garcinia mangostana L.) fruit during ripening and after harvest. Postharvest Biology and Technology 51, 349-353

Pisinger C (2014). A systematic review of health effects of electronic cigarettes. Preventive Medicine 69, 248-260

Raharjo LH, Santoso AL (2013). Gammaglutamyltransferase ( $\mathrm{E} \geq-\mathrm{GT}$ ) serum pada paparan asap rokok gamma-glutamyltransferase ( $\mathrm{E} \geq-\mathrm{GT}$ ) serum on the cigarette. 3, 29-39

Saeki K and Yokomizo T (2017). Identification, signaling, and functions of LTB4 receptors. Seminars in Immunology 33, 30-36

Safyudin S and Subandrate S (2016). Smoking tends to decrease glutathione and increase malondialdehyde levels in medical students. Universa Medicina 35, 89

Santoso AL (2015). Ethanol extract of Mangosteen peel reduces histological count of alveolar macrophage and pulmonary alveolar space size in male white rats (Rattus Norvegicus) exposed to cigarette smoke. Folia Medica Indonesiana 51, 234-244

Sumarny R, Sofiah S, Nurhidayati L (2015). Antioxidant activity of mangosteen ( Garcinia mangostana L .) fruit rind extract in oral solution dosage form aktivitas antioksidan ekstrak kulit buah manggis ( Garcinia mangostana L .) secara bentuk dosis larutan oral. Faculty of Pharmacy J. 7, 1, 6-12

Vendrame S and Klimis-zacas D (2015). Antiinflammatory effect of anthocyanins via modulation of nuclear factor-B and mitogen-activated protein kinase signaling cascades. Nutrition Reviews 73, 348-358

Wiwin S, Endang DW, Lia K (2010). Uji aktivitas antioksidan dan penentuan kandungan antosianin total kulit buah manggis (Garcinia mangostana L.). Majalah Obat Tradisional 15, 64-70 